Маја Ђукановић

Универзитет у Београду

Филолошки факултет $\quad$ 821.163.41.03=163.6

maja.djukanovic@fil.bg.ac.rs hthps://doi.org/10.184855/ai_pesnikinie.2018.ch7

\title{
ПРЕВОДИ ПОЕЗИЈЕ ДЕСАНКЕ МАКСИМОВИЋ НА СЛОВЕНАЧКИ ЈЕЗИК
}

У раду је дат преглед превода поезије српске песникиње Десанке Максимовић на словеначки језик, уз кратак осврт на њене преводе словеначке поезије на српски. Представљању песникиње и песама које су одабране за превођење следи и представљање преводилаца, који су већином и сами књижевни ствараоци. У другом делу рада су представљени преводилачки проблеми у превођењу српске поезије на словеначки језик и дата је анализа преводилачких решења.

Кључне речи: превођење поезије, Десанка Максимовић, преводи са српског на словеначки језик

Код словеначких читалаца се интересовање за дела српске књижевности у већој мери јавља крајем 19. века односно у првој половини 20. века. У то време се на Београдском универзитету одржава и први курс словеначке књижевности за заинтересоване студенте - будуће преводиоце. Предавања је одржао професор Павле Поповић 1905. године, а две године касније исти овај професор организовао је и курс словеначког језика. У периоду између два светска рата, а и касније, у време постојања СФРЈ, у српским читанкама могли су се наћи текстови из словеначке књижевности, штампани у оригиналу уз приложени мали глосар, док се у Словенији српски (српскохрватски) језик учио у основној школи. 
У прегледима и пописима књижевних превода са страних језика на словеначки, преводи српских књижевних дела третирају се као српскохрватски/хрватскосрпски све до 1991. године, односно до времена распада заједничке државе. Од 1991. наовамо преводи са српског језика третирају се независно од превода дела књижевника из Хрватске, Босне и Херцеговине односно Црне Горе.

У периоду између два светска рата, односно у првим годинама постојања заједничке државе, Краљевине Срба, Хрвата и Словенаца, преводилачка активност била је веома жива, а интересовање за књижевно стваралаштво аутора из заједничке државе велико. По завршетку Другог светског рата, у периоду Југославије, превођење у Словенији се мање-више надовезује на преводилачку традицију из периода између два рата. У тим првим послератним годинама преведена су антологијска дела српске књижевности 19. века, као и мањи број остварења из 20. века, а није била занемарена ни савремена књижевност. Велики ентузијазам књижевних преводилаца који су објављивали своје преводе у периоду између два рата, наставио се и после 1945, а резултат њиховог залагања су драгоцени преводи антологијских дела и дела из области фолклорне књижевности.

Средином 20. века, од 1950. до 1955. на словеначки су преведена и дела српских савременика, на пример Ћосићев роман Далеко је суние и Лалићева Сваgба, оба објављена 1952. У исто време се и у књижевној периодици све чешће објављују преводи из српске књижевности, али се примећује нешто слабије интересовање уредника за објављивање превода дела и одломака који су излазили у то време у Србији, него је пажња усмерена на већ позната и призната остварења. Године 1953. и 1954. број књижевних превода са српског на словеначки језик пада на минимум: објављена су само три, односно четири наслова, за разлику од 8 до 12 насло- 
ва објављиваних претходних година. Након 1954. број књига преведених са српског поново расте, тако да између 1959. и 1963. достиже чак 30 наслова годишње (Ротар 1973: 122).

Преводиоци који су се бавили превођењем са српског између два рата и у послератном периоду већином су и сами били књижевни ствараоци. Ту се налазе имена као што су: А. Градник, И. Груден, М. Кметова, П. Флере, Ф. Албрехт, Д. Рављен, Ј. Зупанчич, Б. Борко, М. Рупел. С. Шкерљ, Ј. Видмар, Л. Нови, Л. Мрзел... Југословенска „нобеловска“ година је била веома подстицајна за издаваче, са којима су преводиоци из послератне генерације, међу којима се налазе, између осталог, Јанко Модер, Тоне Потокар, Јоже Удович, Миха Јаворник, познати по својим захтевним и високим преводилачким критеријумима, нашли заједнички језик и успели су да читалачкој публици представе репрезентативна послератна, али и предратна дела српске књижевности. У то време влада велико интересовање читалаца и за мемоарску, односно политичко-публицистичку литературу, па се на словеначки преводе и аутори као што су В. Дедијер, Т. Чолаковић, С. Куленовић, М. Пијаде, А. Билас и други.

Шездесетих година 20. века се избор дела из српске књижевности проширује, па се све чешће објављују и дела из области српске омладинске књижевности. Све чешће се објављују и преводи поезија, а велики успех међу словеначким читаоцима постиже превод славне Анйолоїије новије срӣске лирике Богдана Поповића, коју је за словеначко тржиште приредио Јанко Јуранчич, а поезија која је у њој представљена била је одлична најава за предстојеће преводе савремене српске поезије. Пре тога је антологија српске поезије објављена у преводу Алојза Градника 1948. године.

Године 1955. у Словенији је објављена збирка песама Десанке Максимовић у преводу словеначког 
песника Лојза Кракара, под насловом Pomladne pesmi. Овај превод је објављен у периоду кад је на словеначком тржишту књига владало велико интересовање за српску поезију и у годинама кад су објављени преводи поезије Скендера Куленовић, Оскара Давича, Васка Попе и са великим публицитетом превод Горског вијенца П. П. Његоша.

Године 1966. словеначки писац Вено Тауфер објављује преводе песама Десанке Максимовић у оквиру тројезичне збирке песама. У том периоду, 50-их и 60-их година 20. века код словеначких читалаца, али пре свега код словеначких књижевника, влада велико интересовање за стваралаштво ове славне српске песникиње. Десанка Максимовић је радо посећивала Словенију и међу словеначким колегама је имала доста пријатеља. Српским читаоцима је својим преводима приближила словеначку поезију, а лепоте словеначке природе опевала је у циклусу песама под насловом Из Словеначке.

Поезију Десанке Максимовић су преводили признати словеначки књижевници, као што су Иван Минати, Цирил Злобец, Тоне Павчек, Лојзе Кракар, Вено Тауфер, Павле Голиа, Цветко Загорски, Миле Клопчич, а објављени су преводи око 60 њених наслова. Њена популарност међу читаоцима је у то време била велика, њени стихови су објављивани не само у књижевним издањима, него и у популарним часописима и магазинима намењеним и деци и одраслима (Ciciban, Pionirski list, Naša žena, Borec, Delo, Tovariš...).

До краја 80-их година 20. века у Словенији су објављена бројна књижевна издања песама Десанке Максимовић: 1949. Фрањо Смерду објављује Pesmi v prozi, Миле Клопчич 1952. у збирци Divji grm међу преводима многобројних песника објављује и превод стихова Десанке Максимовић, Лојзе Кракар 1955. преводи збирку Pomladna pesem, Иван Минати 1956. објављује 
наслов Vetrova uspavanka, 1960. Лојзе Кракар објављује превод чувене Крваве бајке, Јанко Модер 1961. Pravljica o enodnevnici, Северин Шали 1964. објављује превод дечјих песама под насловом Nahod v živalskem vrtu, Цветко Загорски 1965. Nočem s tem vlakom, Вено Тауфер 1966. у тројезичној збирци штампа Terjam pomilostitev, Bepa Албрехт 1967. Izvolite na razstavo, Bajka o labodu, Иван Минати 1968. чувени Travniški zvonček, 1974. Vetrova uspavanka, а Цветко Загорски 1979. преводи и штампа наслов Zgodba o razvajeni cesarični (Модер: 1985).

Може се рећи да су преводи објављивани у часописима, ревијама и магазинима били нека врста доказа о популарности одређених аутора, односно о заинтересованости читалаца за одређену књижевност. Они су увек претходили већим књижевним издањима и донекле утицали на одлуке о томе шта ће се штампати у облику песничких збирки. Десанка Максимовић је тако у словеначкој периодици била заступљена и у часописима за децу, као аутор популарних дечјих песама, али и у часописима намењеним широкој публици, као аутор љубавних и родољубивих стихова.

Занимљиво је да се критичари нису често, или чак уопште, оглашавали у вези са квалитетом превода, њиховим језичко-стилским и изражајним квалитетима. У стручној литератури се у то време изузетно ретко наилази на похвале или покуде превода.

Поезија Десанке Максимовић се на словеначки преводила у време када је српска поезија била пуна предлога и смерница у ком правцу треба да се развија. Међутим, песникиња, како критичари сматрају, није прихватала утицај тада модерних трендова, него је, као јака песничка личност, развила свој особени стил, по којем је остала упамћена у историји књижевности. Мелодија њених стихова је попут говора, језик жубори и 
пева, а управо то су елементи које је најтеже преточити у поново исказати у неком другом језику, са другачијим ритмом и другачијом мелодичношћу. Њени стихови имају веома разнолик ритам, одликују се различитим алитерацијама и оригиналношћу рима. Песме Десанке Максимовић су пуне емоција, које читаоца обузимају већ код првог контакта са њеним стиховима, не заборављају се и остају препознатљива одлика песникињиног стила. Поезија Десанке Максимовић се може окарактерисати као исповедна, пуна емоција, у непрестаној жељи да овековечи тренутак. Њене похвале слободи, песме о поробљености, у којима се преплићу различите снажне емоције, резултују емоцијама које су директне и природне (Кракар 1963: 459-560).

Десанка Максимовић је и сама била врстан преводилац са неколико језика, а српским читаоцима је омогућила да на свом језику читају и словеначке песнике. Превела је стихове највећих и најзначајнијих словеначких аутора: Франца Прешерна, Отона Жупанчича, Антона Ашкерца, Ига Грудена, Лојза Кракара, Франца Бевка, Симона Грегорчича, Франа Албрехта, Мире Михелич, Милета Клопчила, Вере Албрехт и других (Модер 1985: 179). Имена аутора чија је дела преводила сведоче да је опус њених превода веома разноврстан, дела су стилски различита, а од преводиоца захтевају велику умешност и изражајност. Непрестана дилема преводилаца поезије, да ли је важније сачувати ритам и форму или се пак држати тога да превод буде језички веран и тачан, огледа се и у напомени коју је записала уз превод познате песме Отона Жупанчича „Песниче, дужност своју знаш“, где каже да је песма преведена рииммованом йрозом, како би се пажња читалаца усмерила за значење оригиналног текста. Нешто касније, песникиња је објавила и другу варијанту превода Жу- 
панчичевих стихова, где је унела озбиљније трансформације песничке слике оригинала (Сибиновић 1979: 172-174). Преводи Десанке Максимовић са словеначког језика јесу преводи који су били објављивани у школским читанкама, тако да се може рећи како је ова песникиња била спона између српске и словеначке књижевности, а на одличан начин је српским читаоцима приближила словеначку поезију.

Преводиоци поезије Десанке Максимовић на словеначки језик су већином и сами песници. Од преводилаца њене поезије међу најзначајније словеначке песнике спадају Лојзе Кракар, Иван Минати и Вено Тауфер.

Лојзе Кракар (1926-1995), слависта, историчар књижевности, есејиста, утицајни словеначки песник, и сам се бавио превођењем поезије са српског, пољског и немачког, аутор је песама које су познате и признате у словеначкој савременој књижевности. Поезију Десанке Максимовић је познавао веома добро, детаљно је анализирао њен песнички стил и представио га у стручној славистичкој литератури (Кракар 1963). Наглашава да је Десанка Максимовић веома заслужна за представљање словеначке поезије у Србији, пре свега својим преводима, али и за представљање саме Словеније својим стиховима. Лојзе Кракар у свом есеју посвећеном овој великој српској песникињи закључује: „Лирика Десанке Максимовић током више од пет деција њеног стваралаштва није изгубила ништа од свежине и оригиналности. Њена поезија служи људима који јесу и људима којих нема, служи час ведрим, час забринутим лицем, од њених девојачких дана до сада, кад је записала 'Немам више времена'. Али време Десанки не може ништа. У југословенском ватреном витлању песничким мачевима и копљима, што људима често одузима снагу и време, Десанка стоји у свом свету и 
сунцу као велика слика нечега што је право и што нико не може да негира.“ (Кракар 1963: 461)

Иван Минати (1924-2012), један од најзначајнијих савремених словеначких песника, као и Лојзе Кракар, лично је познавао Десанку Максимовић и преводио је њену лирику. Десанка Максимовић је превела више Минатијевих дела, од којих су нека нађена необјављена, у рукопису у њеној заоставштини. Иван Минати је на словеначки језик са великом пажњом и песничким умећем превео њену дечју песму „Ливадско звонце“ („Travniški zvonček"), која је постала саставни део словеначких дечјих песмарица.

Вено Тауфер (1933-) познати словеначки писац, песник и есејиста, уједно је и један од најзначајнијих савремених словеначких књижевних преводилаца, који је словеначким читаоцима приближио бројна дела светске књижевности, а међу њима и поезију Десанке Максимовић. Његовом заслугом је словеначким читаоцима доступан превод чувених стихова „Тражим помиловање“, а превод је објављен 1966. у заједничком издању издавача Državna založba Slovenije, Македонске књиге и Просвете. За своје књижевне преводе Вено Тауфер је добио више значајних награда.

Имена преводилаца поезије Десанке Максимовић на словеначки језик, међу којима се налазе имена највећих словеначких савремених песника, сведоче о значају који јој је дат у словеначкој преводној књИжевности. Широк спектар њених стихова, заступљен у најразличитијим књижевним и ревијалним издањима, говори о томе да је њена поезија радо читана и да је словеначким читаоцима блиска. Успешни преводи поезије Десанке Максимовић доприносе да њена поезија заузима значајно место у словеначкој култури, а прихваћеност међу читаоцима која не јењава сведочи о њеној несумњивој песничкој величини. 
Преводи поезије Десанке Максимовић...

Литература

Krakar Lojze. "Desanka Maksimovič.” Sodobnost (1963) letnik 29. številka 5 (1981).

Moder, Janko. Slovenski leksikon novejšega prevajanja. Koper: Založba Lipa, 1985. Štampano.

Rotar, Janez. "Prevajanje iz hrvaške in srbske književnosti v slovenščino po letu 1945.” Jezik in slovstvo letnik 18. številka 4 (1973) str. 121-128.

Сибиновић, Миодраг. Ориіинал и йревоg. Увоg у исйорију и

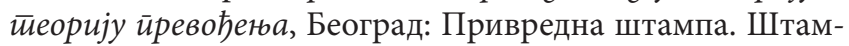
пано.

\section{Maja Đukanović}

\section{TRANSLATIONS OF SERBIAN POETESSES INTO SLOVENIAN}

\section{Summary}

This paper presents a review of the translation of Serbian poetry into the Slovenian language, with special emphasis on the poetry of Serbian poetesses. This overview of the poetesses and their poetry translated into Slovenian is followed by an overwiew of their translators, mostly poets and writers themselves. In the second part of the paper, the author analyzes the translations of the poems of a Serbian poetess, Desanka Maksimovic, so as to illustate the translation problems and solutions, and the possible assessment of the quality of these translations.

Key words: translation, Slovenian language. 